\title{
Prokrastinasi Akademik Ditinjau Dari Adversity Quotient Dalam Mengerjakan Skripsi Pada Mahasiswa
}

\author{
Christover, Rianda Elvinawanty \\ Universitas Prima Indonesia, Indonesia \\ Email: christrst@gmail.com
}

\begin{abstract}
The study aims to determine the relationship between adversity quotient and academic procrastination. The hypothesis proposed in this study stated that there was a negative relationship between adversity quotient and academic procrastination, assuming the higher quality of adversity quotient and the lower academic procrastination, and conversely the lower quality of adversity quotient and the higher academic procrastination. Subjects used in this study were Student of STIE Eka Prasetya Medan consisting of 105 people who were selected by using total sampling technique. Data were obtained from a scale to measure quality of adversity quotient and academic procrastination. The calculation was performed by means of testing requirements analysis (assumption test) that consists of a test for normality and linearity. Analysis of the data used was performed by Product Moment Analysis through SPSS 20 for Windows. The results of data analysis showed that $r=-0,844$ and $\mathrm{p}=0.000(\mathrm{p}<0.05)$, indicating that there was a negative relationship between adversity quotient and academic procrastination. The results of this study indicated that the contribution $\left(\mathrm{R}^{2}\right)$ given to the quality of adversity quotient to academic procrastination was $71.2 \%$, the remaining $28.8 \%$ were affected by other factors not examined. From these results it can be concluded that the hypothesis is acceptable.
\end{abstract}

Keywords: academic procrastination, adverstiy quotient, college students

\begin{abstract}
Abstrak
Dalam Penelitian ini berisi tentang mengetahui relasi antara adversity quotient dan prokrastinasi akademik. Hasil yang di perkirakan dari peneitian ini berupa adanya hubungan negatif antara adversity quotient dan prokrastinasi akademik, dengan perkiraan hasil semakin tinggi adversity quotient maka semakin rendah prokrastinasi akademik dan sebaliknya. Subjek penelitian yang digunakan dalam penelitian ini adalah mahasiswa/mahasiswi di STIE Eka Prasetya Medan sebanyak 105 orang yang dipilih dengan menggunakan total sampling. Data yang didapatkan untuk mengukur adversity quotient dan prokrastinasi akademik dari skala. Proses kalkulasi dimulai dengan menguji prasyarat analisis (uji asumsi) yang terdiri dari uji normalitas dan uji linearitas. Untuk Analisis data menggukan Analisa Product Moment dengan bantuan SPSS 20 for Windows. Hasil Proses analisis data menampilkan $\mathrm{r}=-0.844$, dan $\mathrm{p}=0.000(\mathrm{p}<0.05)$ yang menggambarkan bahwa terdapat relasi negatif antara adversity quotient dan prokrastinasi akademik. Hasil penelitian ini menunjukkan bahwa hasil $\left(\mathrm{R}^{2}\right)$ yang diberikan variabel adversity quotient terhadap prokrastinasi akademik adalah sebesar 71.2 persen, selebihnya 28.8 persen disumbangi oleh faktor lain yang tidak diteliti. Dari hasil penelitian memberkan kesimpulan bahwa hipotesis yang diajukan dapat diterima.
\end{abstract}

Kata kunci: prokrastinasi akademik, adversity quotient, mahasiswa

\section{Pendahuluan}

Mahasiswa merupakan sebuah sebutan orang yang sedang dalam tahapan melanjutkan pendidikan formal ke jenjang yang lebih tinggi yaitu pada tingkat sarjana. Menurut Sutrisman (2019), mahasiswa adalah orang yang belajar di perguruan tinggi, baik di universitas, atau institut. Perguruan Tinggi merupakan suatu lembaga pendidikan yang secara formal memberikan tugas dan tanggung jawab mempersiapkan mahasiswa. Tujuan pendidikan tinggi dapat tercapai apabila tridharma perguruan tinggi dapat terlaksana, yaitu mampu menyelenggarakan pendidikan, melakukan penelitian dan melakukan pengabdian pada masyarakat. Salah satu tugas yang harus ditempuh oleh semua mahasiswa adalah menyelesaikan skripsi untuk memperoleh gelar sarjana. Mutaqin (2018) menjelaskan, skripsi adalah karya tulis ilmiah yang disajikan mahasiswa dalam bentuk laporan penelitian. Mahasiswa dituntut untuk bisa bertindak dan menghasilkan karya secara mandiri dan memiliki tanggung jawab untuk menyelesaikan tugas-tugas akademiknya. Dalam proses mengerjakan skripsi, bukan suatu hal yang mudah dilalui oleh mahasiswa, banyak kendala yang dihadapi dan tentu harus ada pengorbanan yang dilalui untuk memperoleh gelar sarjana. Kesuksesan dapat diraih apabila adanya kerja keras, mampu memanajemen waktu serta ketahanan dalam menghadapi kesulitan dengan baik. Manajemen waktu tidaklah mudah, banyak orang yang tidak mampu memanajemen waktunya. 
Manajemen waktu yang baik artinya individu mampu mengelola waktu dengan efektif sehingga efesiensi waktu menjadi sangat penting sehingga waktu tidak terbuang sia-sia. Hal ini dapat kita lihat dari masih banyaknya orang yang menunda dan mengulur waktu ketika diberikannya suatu tugas atau kewajiban (Hayati, 2017). Salah satu kasus yang terjadi pada seorang pria bernama Maulana berusia 22 tahun biasa melakukan penundaan sampai dengan menit-menit terakhir apabila tugas yang harus diselesaikan pukul $07.00 \mathrm{WIB}$, ia baru akan serius mengerjakan tugasnya pada malam sebelumnya atau bahkan di dini hari pada tanggal yang sama, ia beranggapan bahwa akan lebih mudah berpikir apabila sudah di kejar oleh deadline semakin dekat batas waktu maka semakin lancar otaknya bekerja (www.kumparan.com). Berdasarkan survei hasil wawancara yang dilakukan terhadap beberapa mahasiswa STIE Eka Prasetya Medan, Mahasiswa mengatakan bahwa mengalami kesulitan dalam proses pengajuan judul, karena mahasiswa jarang membaca sehingga sulit untuk mendapatkan referensi dan judul yang akan digunakan, disisi lain mahasiswa juga mengatakan bahwa tidak memiliki waktu karena mahasiswa kuliah sambil bekerja sehingga tidak memiliki waktu luang untuk membaca. Mahasiswa mengatakan bahwa ketentuan dalam pengajuan judul adalah mencari minimal 3 (tiga) buah variabel bebas ditambah dengan 1 (satu) buah variabel terikat. Mahasiswa juga mengatakan sebelumnya sudah sempat diterima dalam proses pengajuan judul namun pada akhirnya kesulitan untuk menemukan referensinya sehingga memutuskan untuk menganti judul yang baru, hal ini yang membuat mahasiswa memilih untuk menunda proses pengerjaan tugas akhirnya. Ada juga mahasiswa lain mengatakan bahwa deadline yang diberikan masih lama sehingga mahasiswa lebih mementingkan tugas lain yang harus dikumpulkan terlebih dahulu, namun pada akhirnya pada saat deadline yang diberikan sudah dekat mahasiswa mengatakan kesulitan dalam menyelesaikannya tugas yang diberikan sehingga tugas pun tidak dapat terselesaikan karena mahasiswa cenderung mengulur-gulur waktu untuk menyelesaikannya. Serta ada juga mahasiswa yang tidak menganggap bahwa tugas akhir merupakan suatu hal yang harus di prioritaskan sehingga mahasiswa lebih mementingkan tugas pekerjaannya. Berdasarkan hasil survei wawancara di STIE Eka Prasetya dapat dilihat bahwa mahasiswa/mahasiswi yang sedang mengerjakan skripsi memiliki tingkat kecenderungan untuk menunda-nunda pekerjaan. Dalam ilmu Psikologi kecenderungan seseorang untuk menunda-nunda dalam memulai atau menyelesaikan suatu tugas atau pekerjaan disebut dengan Prokrastinasi. Istilah prokrastinasi berasal dari bahasa latin procrastinus dengan awalan pro yang berarti meneruskan atau mendorong untuk maju atau bergerak maju dan crastinus yang berarti keputusan hari esok. Jika digabungkan procarstinus adalah meneruskan hari esok atau dengan kata lain berarti "saya akan melakukannya nanti” (Burka \& Yuen, 2008). Menurut Hidayah dan Atmoko (2014), perilaku menunda dapat berdampak fatal seperti berperilaku tidak disiplin, prestasi belajar rendah, pada gilirannya memicu peserta didik terancam drop-out.

Salah satu faktor yang mempengaruhi prokrastinasi akademik adalah adversity quotient. Adversity quotient adalah seberapa jauh kemampuan seseorang untuk dapat bertahan ketika menghadapi kesulitan dan dapat mengatasi kesulitan-kesulitannya. Banyak orang yang menyerah sebelum bertanding ketika berhadapan dengan tantangan-tantangan hidup. Individu tidak akan pernah tahu seberapa besar usaha dan batas kemampuan yang benar-benar teruji, tidak sedikit orang yang jelasjelas cerdas namun gagal menunjukkan potensi dirinya (Habsari, 2005). Berdasarkan hasil penelitian yang dilakukan oleh Qomari (2015), menunjukkan bahwa apabila siswa memiliki salah satu dimensi adversity quotient: kendali diri, origin and ownership, jangkauan, dan daya tahan maka kecenderungan melakukan perilaku prokrastinasi akademik akan rendah. Hal ini menggambarkan apabila tingkat adversity qotient seorang tinggi maka kecenderungan untuk melakukan perilaku prokrastinasi akan rendah.

Berdasarkan hasil kajian literatur yang ada, terdapat peneliti yang telah melakukan penelitian untuk menunjukkan bahwa adanya hubungan adversity quotient dengan prokrastinasi akademik. Salah satu hasil penelitian oleh Sanusi, dkk., (2017) pada sejumlah PG PAUD Fakultas Keguruan dan Ilmu Pendidikan Universitas Riau angkatan 2014 yang dapat disimpulkan bahwa apabila mahasiswa dapat meningkatkan adversity quotient untuk dapat terus menghadapi permasalahan khususnya dalam bidang akademik, perilaku prokrastinasi akademik akan dihindari karena semakin tinggi adversity quotient maka kecenderungan melakukan prokrastinasi akademik akan menurun.

Berdasarkan uraian di atas dan fenomena-fenomena yang berkaitan pada tingginya perilaku prokrastinasi akademik pada individu dalam menyelesaikan tugasnya sehingga diperlukannya suatu kemampuan/kecerdasan dalam mengatasi/mengurangi perilaku prokrastinasi akademik yang muncul, 
maka peneliti tertarik untuk mengambil judul penelitian "Prokrastinasi Akademik ditinjau dari Adversity Quotient dalam mengerjakan skripsi pada mahasiswa/mahasiwi STIE Eka Prasetya Medan". Tujuan dilakukannya resersh ini adalah mencari relasi dari adversity quotient dengan prokrastinasi akademik.

\section{Metode Penelitian}

Untuk melakukan proses analisis lanjutan terhadap penelitian ini maka perlu melakukan tahapan identifikasi variable sedangkan variable - variable yang digunakan pada penelitian penelitian ini yaitu prokrastinasi akademik sebagai variabel tergantung dan adversity quotiet sebagai variabel bebas. Keseluruhan subjek dalam penelitian ini di jadikan subjek penelitan. Soewadji (2012) mengatakan bahwa populasi adalah sekelompak unsur atau elemen yang dapat berbentuk manusia atau individu, binatang, tumbuh-tumbuhan, lembaga atau institusi, kelompok, dokumen, kejadian, sesuatu hal, gejala, atau berbentuk konsep yang menjadi objek penelitian. Hal yang sama diungkapkan oleh Sugiyono (2011), mahasiswa tingkat akhir di STIE Eka Prasetya Medan Semester 7 yang berjumlah 105 orang di jadikan Objek yang mencukupi persyaratan dan memenuhi karakter populasi dalam penelitian ini kemudian di cari kesimpulan.

Objek penelitian adalah sebagian saja dari seluruh jumlah populasi, yang diambil dari populasi dengan sedemikian rupa sehingga dapat dianggap mewakili seluruh anggota populasi (Soewadji, 2012). Melihat jumlah populasi yang relatif sedikit, maka teknik sampling yang digunakan adalah teknik total sampling, yakni seluruh anggota populasi dijadikan sebagai sampel penelitian (Sugiyono, 2011). Adapun jumlah sampel yang dalam penelitian ini adalah kesuluruhan jumlah populasi yaitu 105 Mahasiswa/I STIE Eka Prasetya Medan Semester 7 yang sedang tahap proses mengerjakan skripsi.

Metode yang dilakukan dalam proses pengumpulan data dalam penelitian ini adalah dengan cara menyebarkan kuesioner (angket) penelitian kepada subjek yang sudah ditentukan sebelumnya. Kusioner merupakan seperangkat pertanyaan atau pernyataan tertulis kepada responden untuk dijawab atau dikerjakan (Sugiyono, 2011).

Penelitian ini disusun menggunakan dua skala yaitu skala prokrastinasi akademik dan adversity quotient. Skala prokrastinasi akademik disusun berdasarkan ciri prokrastinasi yang dikemukakan oleh Ferrari., dkk. (dalam Ghufron \& Risnawati, 2010). Skala adversity quotient yang dikemukan oleh Stoltz (2000) antara lain: dimensi control, origin \& ownership, reach, endurance.

Subjek diminta untuk meminta salah satu dari keempat alternatif jawaban yang disediakan sesuai dengan keadaan subjek. Skala ini disajikan dalam bentuk pernyataan yang bersifat favourable dan unfavourable. Kriteria penilaian aitem favourable bergerak dari skor 1 (satu) untuk jawaban Sangat Tidak Setuju (STS), skor 2 (dua) untuk jawaban Tidak Setuju (TS), skor 3 (tiga) untuk jawaban Setuju (S), dan skor 4 (empat) untuk jawaban Sangat Setuju (SS). Sedangkan untuk aitem unfavourable, skor 1 (satu) untuk jawaban Sangat Setuju (SS), skor 2 (dua) untuk jawaban Setuju (S), skor 3 (tiga) untuk jawaban Tidak Setuju (TS) dan skor 4 (empat) untuk jawaban Sangat Tidak Setuju (STS).

Jenis validitas dalam penelitian ini menggunakan validitas isi. Menurut Azwar (2012) validitas isi menggunakan keputusan akal sehat mengenai keselarasan atau relevansi aitem dengan tujuan ukur skala tidak dapat didasarkan hanya pada penilaian penulis soal sendiri, tapi juga memerlukan kesepakatan penilaian dari beberapa penilai yang kompeten (expert judgement). Proses uji validitas menggunakan rumus Corrected Item Total Correlation dengan bantuan SPSS (Statistical Peckage for Social Sciences) 20 for Windows pada komputer.

Setelah dilakukannya uji validitas, dilakukan uji reliabilitas alat ukur. Menurut Sugiyono (2011), instrumen yang reliable adalah instrumen yang bila digunakan beberapa kali untuk mengukur objek yang sama, akan menghasilkan data yang sama. Reliabilitas dinyatakan dalam koefisien, dengan angka antara 0 (nol) sampai 1,00 (satu). Semakin tinggi koefisien mendekati angka 1,00 (satu) berarti reliabilitas alat ukur semakin tinggi. Sebaliknya reliabilitas alat ukur yang rendah ditandai oleh koefisien reliabilitas yang mendekati angka 0 (nol) (Azwar, 2012). Penelitian ini menggunakan teknik Alpha Cronbach untuk menguji reliabilitas dengan menggunakan bantuan program SPSS (Statistical Peckage for Social Sciences) 20 for Windows pada komputer.

Teknik analisis data yang digunakan dalam penelitian ini adalah teknik korelasi Person Product Moment dengan menggunakan bantuan program SPSS (Stastistical Peckage for Social Sciences) for windows pada komputer. Alasan digunakannya metode ini adalah agar dapat diketahui hubungan antara adversity quotient dengan prokrastinasi akademik. 
Korelasi Person Product Moment mensyaratkan bahwa data harus berdistribusi dengan normal, dan dalam hal ini menggunakan teknik analisis Kolmogorov Smirnov $Z$ untuk mengetahui apakah distribusi data penelitian masing-masing variabel telah terdistribusi secara normal atu tidak. Menurut Priyanto (2011), aspek yang perlukan untuk menentukannya adalah jika $\mathrm{P}>0,05$ bisa disebut data terbagikan secara normal dan begitu sebaliknya ketika $\mathrm{P}<0,05$ bisa di sebut data terbagikan secara tidak normal. Uji linearitas dilakukan menggunakan prosedur analisis statistis korelasional bertujuan untuk mengetahui apakah dua variabel yang digunakan menunjukkan hubungan yang linear atau tidak. Menurut Priyanto (2011), jika $\mathrm{p}<0,05$ bisa di katakana relasi antara prokrastinasi akademik dan adversity quotient linear. Begitu juga Sebaliknya jika $\mathrm{P}>0,05$ maka kedua variable tadi dikatakan tidak linear.

\section{Hasil dan Pembahasan}

Penelitian ini dilaksanakan di STIE Eka Praseya Medan, Sumatera Utara. STIE Eka Praseya Medan adalah sekolah tinggi ilmu ekonomi yang berada di Kota Medan tepatnya di Jalan Merapi No.8, Pusat Ps., Kec. Medan Kota, Kota Medan, Sumatera Utara 20212. STIE Eka Prasetya diresmikan oleh Bapak Walikota Medan Drs. H. Abdillah, Ak, MBA pada tanggal 23 April 2006 dan tanggal tersebut ditetapkan sebagai Dies Natalis STIE Eka Prasetya . Kemudian pada tahun 2014 Yayasan Worldstar Education berubah nama menjadi Yayasan Graha Eka Education Center (dikarena pengurusan Pengesahan nama Yayasan Ke Kementrian Hukum dan Hak Azasi Manusia di Jakarta) dan perubahan nama tersebut telah dilaporkan ke Kopertis Wilayah I Sumatera Utara dan ke Direktorat Jenderal Pendidikan Tinggi dan pada tahun 2016 dengan resmi STIE Eka Prasetya berada dibawah naungan Yayasan Graha Eka Education Center. STIE Eka Praseya merupakan kampus yang lahir dengan konsep pendidikan berkarakter karier, jam perkuliahan yang ramah dengan jam kerja, dan memiliki dosen-dosen praktisi yang berpengalaman.

Uji coba skala dilakukan di STIE IBBI Medan, Sumatera Utara pada tanggal 22 Juli 2019. Adapun subjek uji coba skala adalah mahasiswa/i STIE IBBI Medan yaitu 66 orang yang sedang dalam tahap mengerjakan skripsi. Alasannya bahwa jumlah populasi terbatas, sehingga hanya sebagian yang bisa diambil sebagai subyek sampel uji coba, dengan harapan subyek uji coba mempunyai ciri-ciri dan karakteristik yang sama dengan subyek penelitian.

Pada skala prokrastinasi akademik, hasil analisis butir menunjukkan bahwa 32 dari 40 aitem dinyatakan sahih dimana aitem yang valid dengan nilai $r$ bergerak dari 0,307-0,777 dengan nilai koefisien reliabilitas 0.931 . Hal ini menunjukkan bahwa skala dalam uji coba layak digunakan sebagai alat pengumpulan data dalam penelitian.

Pada skala adversity quotient, hasil analisi butir menunjukkan bahwa 28 dari 40 aitem dinyatkan sahih dimana aitem yang valid dengan nilai $r$ bergerak dari $0,358-0,625$ dengan nilai koefisien reliabilitas 0.917. Hal ini menunjukkan bahwa skala dalam uji coba layak digunakan sebagai alat pengumpulan data dalam penelitan.

Penelitian dilakukan pada tanggal 25 Juli 2019 pada 105 mahasiswa/mahasiswi di STIE Eka Prasetya yang sedang dalam proses mengerjakan skripsi. Skala prokrastinasi akademik terdiri dari 32 aitem yang mana skor dari aitem berada diantara 4 pilihan milai dari satu sampai empat. Batas atas dan bawahnya adalah adalah $32 \times 1$ - 32x4, yaitu 32 sampai 128 dengan mean hipotetiknya $(32+128): 2=$ 80. (128-32) : $6=16$. Adalah standardeviasia yang di pakai dari skala prokrastinasi akademik yang subjeknya terisi, jika mendapatkan hasil mean empirik sebesar 81.54 sebagai standar deviasi 6.770. Perbandingan data empiris dan data hipotesis disajikan pada tabel 1.

\begin{tabular}{|c|c|c|c|c|c|c|c|c|}
\hline \multirow{2}{*}{$\frac{\text { Variabel }}{\text { Prokrastinasi }}$} & \multirow[b]{2}{*}{ Min } & \multirow{2}{*}{\multicolumn{2}{|c|}{$\frac{\text { Empirik }}{\text { Mean }}$}} & \multirow{2}{*}{ SD } & \multicolumn{3}{|c|}{ Hipotetik } & \multirow{2}{*}{ SD } \\
\hline & & & & & Min & $\operatorname{Max}$ & Mean & \\
\hline Akademik & 64 & 115 & 95.34 & 9.841 & 32 & 128 & 80 & 16 \\
\hline
\end{tabular}

Hasil proses analisis skala prokrastinasi akademik didapatkan mean empirik < mean hipotetik yaitu $95.34>80$ jadi kesimpulannya adalah prokrastinasi akademik subjek penelitian menunjukkan kategori sedang. Tidak janjutnya subjek akan dipisahkan ke beberapa kategori prokrastinasi akademik. Pengkategorian prokrastinasi akademik dengan membuat pembahagian normal sebayak enam bagian 
kedalam bagian penyimpangan standar. Standar deviasi hipotetik yang di gunakan dalam research ini adalah $\sigma=(128-32): 6=16$ dan mean hipotetiknya adalah $\mu=(32+128): 2=80$. Hasil penelitian ini bisa dijadikan hitung - hitungan dasar untuk rumus yang telah di sampaikan di atas, maka didapatkan $\mathrm{x}$ $<(80-16)=64,(80-16) \leq \mathrm{x}<(80+16)=64 \leq \mathrm{x}<96$, dan $\mathrm{x} \geq(80+16)=\mathrm{x} \geq 96$. Hasil dari perhitungan, dapat dibuat kategorisasi pada Tabel 2 berikut ini.

\begin{tabular}{ccccc}
\multirow{2}{*}{ Variabel } & \multicolumn{2}{c}{ Tabel 2. Kategorisai Data Prokrastinasi Akademik } & Persentase \\
\hline \multirow{2}{*}{$\begin{array}{c}\text { Prokrastinasi } \\
\text { Akademik }\end{array}$} & $\mathrm{x}<64$ & Kategori & Jumlah $(\mathrm{n})$ & $0 \%$ \\
\cline { 2 - 5 } & $64 \leq \mathrm{x}<96$ & Rendah & 0 & $50 \%$ \\
\hline & $\mathrm{x} \geq 96$ & Sedang & 52 & $50 \%$ \\
\hline
\end{tabular}

Dari table 2 menampilkan bahwa prokrastinasi akademik pada kategori bawah sebesar ( 0 persen), kategori tengah beranggotakan 101 orang dengan perentase senilai 96.2 persen sedangkan subjek prokrastinasi akademik yang cocok dengan kategori sebanyak 3.8\% atau 4 orang. Berdasarkan penjelasan di atas, jadi bisa di Tarik kesimpulan bahwa terdapat sebanyak 0\% subjek masuk dalam katogori rendak prokrastinasi akademiknya, selebihnya di katogorikan prokrastinasi akademik yang sedang dan tinggi. Skala adversity quotient terdiri dari 28 aitem yang hasilnya terdapat 4 jawaban yang skornya bisa diurutkan dari tinggi ke rendahnya adalah $28 \times 1-28 \times 4$, yaitu 28 sampai 112 yang memliki mean hipotetiknya adalah $(28+112): 2=70$. Standar penyimpangan hipotetik didalam paper ini adalah $(112-28): 6=14$. Dari skala adversity quotient yang diberi subjek, dapat diperoleh mean empirik bernilai 81.54 dan standar penyimpangan 6.770. Perbandingan data empiris dan data hipotesis dapat dilihat pada Tabel 3.

\begin{tabular}{|c|c|c|c|c|c|c|c|c|}
\hline \multirow{2}{*}{ Variabel } & \multirow[b]{2}{*}{ Min } & \multirow{2}{*}{\multicolumn{2}{|c|}{$\frac{\text { Empirik }}{\text { Mean }}$}} & \multirow{2}{*}{ SD } & \multicolumn{3}{|c|}{ Hipotetik } & \multirow{2}{*}{ SD } \\
\hline & & & & & Min & Max & Mean & \\
\hline Akademik & 66 & 98 & 81.54 & 6.770 & 28 & 112 & 70 & 14 \\
\hline
\end{tabular}

Hasil analisis dari skala adversity quotient didapatkan mean empirik > mean hipotetik sebesar $81.54>$ 70 jadi bisa di katakan bahwa adversity quotient pada subjek penelitian termasuk tinggi dari pada sekumpulan biasanya. Adversity quotient akan dibagi menjadi 3 bahagian. Pengkategorian adversity quotient dengan menggunakan pembagian pengantaran normal ke dalam enam bahagian standar deviasi. Normal deviasi hipotetik yang di gunakan adalah $\sigma=(112-28): 6=14$ dan mean hipotetiknya adalah $\mu=(28+112): 2=70$. Berdasarkan hitung - hitungan di atas dapat diperoleh $\mathrm{x}<(70-14)=56$, $(70-14) \leq \mathrm{x}<(70+14)=56 \leq \mathrm{x}<84$, dan $\mathrm{x} \geq(70+14)=\mathrm{x} \geq 84$. Table di bawah ini akan melihatkan hasil dari perhitungan.

\begin{tabular}{ccccc} 
& \multicolumn{2}{c}{ Tabel 4. Kategorisai Data Adversity Quotient } & \\
Variabel & Rentang Nilai & Kategori & Jumlah $(\mathrm{n})$ & Persentase \\
\hline \multirow{2}{*}{$\begin{array}{c}\text { Adversity } \\
\text { Quotient }\end{array}$} & $\mathrm{x}<56$ & Rendah & 0 & $0 \%$ \\
\cline { 2 - 5 } & $56 \leq \mathrm{x}<84$ & Sedang & 66 & $62.6 \%$ \\
\hline & $\mathrm{x} \geq 84$ & Tinggi & 39 & $37.4 \%$ \\
\hline
\end{tabular}

berlandaskan katergori pada keterangan tabel di atas, bisa disimpulkan adversity quotient terdapat $0 \%$ subjek di kategori rendah, sedangkan adversity quotient pada subjek yang berada di kategori sedang berangka 66 orang atau $62.4 \%$ dan subjek kategori tinggi berjumlah 39 orang atau $37.4 \%$. dari gambaran di atas, bisa di ambil kesimpulan semua subjek mendapatkan kategori tinggi dan sedang, sedangkan rendah itu tidak ada,

untuk melihat peyebaran uji variable yang di lakukan secara normal maka perlu di lakukan uji normasilasi. Dengan metode uji Kolmogorov Smirnov Test (K-SZ) uji normalisasi di kerjkan. Jika hasil p > 0,05 di katakana normal. Variabel adversity quotient menampilkan nilai nilai K-SZ sebesar 0.785 dengan Sig sebesar 0,569 untuk uji 2 (dua) ekor / Sig. 2-tailed, sedangkan penelitian ini memiliki hipotesis satu arah, sehingga yang dipakai adalah uji 1 (satu) ekor / Sig. 1-tailed sebesar $0.284(p>0,05)$ yang artinya sebaran skor adversity quotient mengikuti distribusi normal. Variabel prokrastinasi akademik menunjukkan nilai K-SZ sebesar 0.972 dengan Sig sebesar 0,301 untuk uji 2 (dua) ekor / Sig 2-tailed, dan untuk Sig. 1-tailed sebesar $0.150(\mathrm{p}>0,05)$ artinya sebaran skor prokrastinasi akademik mengikuti distribusi normal. Berdasarkan hasil tersebut data pada variabel 
adveristy quotient dan prokrastinasi akademik memiliki sebaran atau berdistribusi normal karena $\mathrm{p}>$ 0,05. Hasil uji dapat dilihat di tabel 5.

Tabel 5. Hasil Uji Normalitas

\begin{tabular}{cccccc} 
Variabel & SD & K-SZ & Sig. & P & Keterangan \\
\hline Adversity Quotient & 9.841 & 0.785 & 0.569 & $\mathrm{P}>0,05$ & Sebaran normal \\
\hline Prokrastinasi Akademik & 6.770 & 0.972 & 0.301 & $\mathrm{P}>0,05$ & Sebaran normal
\end{tabular}

Untuk meihat lineritas relasi antar Variabel prokrastinasi akademik dan adversity quotient maka perlu dilakukan uji linearitas. jika $\mathrm{p}<0,05$ bisa disimpulkan hasil dari dua variabel memiliki hubungan linear. Hasil uji dapat dilihat di tabel 6.

\begin{tabular}{cccc} 
& Tabel 6. Hasil Uji Linearitas Hubungan & \\
Variabel & F & Sig & Keterangan \\
\hline $\begin{array}{c}\text { Prokrastinasi Akademik } \\
\text { Adversity Quotient }\end{array}$ & 264.554 & 0,000 & Linear $(\mathrm{P}<0,05)$
\end{tabular}

Berdasarkan Tabel 6 dapat dikatakan bahwa variabel prokrastinasi akademik dan adversity quotient memiliki hubungan linear. Hal ini terlihat dari nilai $\mathrm{P}$ yang diperoleh yaitu 0,000 maka $\mathrm{p}<0,05$ maka dapat disimpulkan adalah kedua variabel memiliki hubungan linear dan telah memenuhi syarat untuk dilakukan analisa korelasi Product Moment.

Setelah uji asumsi diterima selanjutnya dilakukan uji hipotesis. Hipotesis dalam penelitian ini adalah ada hubungan negatif antara adversity quotient dengan prokrastinasi akademik. Pengujian hipotesis dilakukan dengan menggunakan teknik analisis Pearson Correlation. Hasil uji statistik dapat dilihat pada Tabel 7.

\begin{tabular}{lcc}
\multicolumn{2}{c}{ Tabel 7. Korelasi antara prokrastinasi akademik dengan adversity quotient } \\
Analisis & Pearson Correlation & Signifikansi (p) \\
\hline Korelasi & -0.844 & 0.000
\end{tabular}

Berdasarkan hasil analisis korelasi antara adversity quotient dan prokrastinasi akademik, diperoleh koefisien korelasi product moment sebesar -0.844 dengan $\mathrm{p}$ sebesar 0,000 ( $\mathrm{p}<0,05$ : Sig. 1-tailed). Hal ini menunjukkan bahwa adanya korelasi negatif antara adversity quotient dengan prokrastinasi akademik. Dari hasil perhitungan tersebut, maka hipotesis yang diajukan dalam penelitian ini menunjukkan adanya hubungan yang negatif antara adversity quotient dengan prokrastinasi akademik dinyatakan dapat diterima. Dengan demikian dapat disimpulkan bahwa semakin tinggi adversity quotient, maka semakin rendah prokrastinasi akademik dan sebaliknya semakin rendah adversity quotient maka semakin tinggi prokrastinasi akademik mahasiswa/mahasiswi.

\section{Kesimpulan}

Berdasarkan hasil-hasil yang telah diperoleh dalam penelitian ini, maka dapat disimpulkan bahwa ada hubungan negatif antara adversity quotient dengan prokrastinasi akademik yang sedang dalam proses mengerjakan skripsi pada mahasiswa/mahasiswi di STIE Eka Prasetya Medan dengan korelasi (r) 0.844 dengan $\mathrm{p}$ sebesar 0.000 maka $\mathrm{p}<0,05$, artinya semakin tinggi adversity quotient maka semakin rendah prokrastinasi akademik, sebaliknya jika semakin rendah adversity quotient maka semakin tinggi prokratinasi akademik. Mean dari prokrastinasi akademik pada subjek penelitian mahasiswa/I di STIE Eka Prasetya Medan secara kesuluruhan menunjukkan bahwa perilaku prokrastinasi akademik pada subjek penelitian berada pada kategori tinggi. Mean dari adversity quotient pada subjek mahasiswa/I di STIE Eka Praseya Medan secara keseluruhan menunjukkan bahwa adversity quotient subjek penelitian menunjukkan kategori sedang. Hasil penelitian ini menunjukkan bahwa sumbangan yang diberikan variabel adversity quotient terhadap prokrastinasi akademik adalah sebesar 71,2 persen, selebihnya 28,8 persen dipengaruhi oleh faktor lain. 


\section{Daftar Rujukan}

Azwar, S. 2012. Penyusunan Skala Psikologi. Yogyakarta: Pustaka Pelajar.

Burka, J. B. \& Yuen L. M. 2007. Procrastination : Why you do it, what to do about it now. New York: Persues Books. [E-book] (Updated 27 Apr 2007) Tersedia di: https://books.google.com/ [Accessed 27 September 2018]

Ghufron, N. \& Risnawati R. 2010. Teori-teori Psikologi. Yogyakarta: Graha Ilmu.

Habsari, S. 2005. Bimbingan dan Konseling. Jakarta: PT Grasindo. [E-book] Tersedia di: https://books.google.com/ [Accessed 24 Febuari 2019]

Hidayah, N. \& Atmoko, A. 2014. Landasan Sosial Budaya dan Psikologis Pendidikan. Malang: Gunung Samudera. [E-book] (Updated 18 Dec 2014) Tersedia di: https://books.google.com/ [Accessed 24 Febuari 2019]

Hayati, S. 2017. Manajemen Umum \& Sumber Daya Manusia. Yogyakarta: ANDI. [E-book] Tersedia di: https://books.google.com/ [Accessed 24 Febuari 2019]

Kumparan. 2018. Untukmu yang Suka Menunda Pekerjaan [Online] (Updated 6 Jan 2018) Tersedia di: https://kumparan.com/ [Accessed 23 Febuari 2019]

Mutaqin, D. Z. 2018. Buku Panduan Penyusunan Skripsi. Yogyakarta: Deepublish. [E-book] (Updated 27 Jul 2018) Tersedia di: https://books.google.com/ [Accessed 22 Febuari 2019]

Priyatno, D. 2011. Buku Saku Analisis Statistik SPSS. Jakarta: Abadi.

Qomari, M. N. 2015. Hubungan antara Adversity dengan Prokrastinasi Akademik Siswa di SMP Insan Cendekia Mandiri Boarding School Sidoarjo, 10 (2), pp.127-138.

Sanusi, M., Zulkifli, N., \& Risma, D. 2017. Hubungan Adversity Quotient dengan Prokrastinasi Akademik Mahasiswa Program Studi PG PAUD Fakultas Keguruan dan Ilmu Pendidikan Universitas Riau Angkatan 2015. 4 (2).

Stoltz, 2000. Adversity Quotient : Mengubah Hambatan Menjadi Peluang. Jakarta: PT. Gramedia Indonesia. [Ebook] Tersedia di: https://books.google.com/ [Accessed 27 September 2018]

Soewadji, J. 2012. Pengantar Metode Penelitian. Jakarta: Mitra Wacana Media.

Sugiyono. 2011. Metode Penelitian Administrasi. Bandung: Alfabeta

Sutrisman, D. 2019. Pendidikan Politik, Persepsi, Kepemimpinan, dan Mahasiswa. Jakarta: Guepedia Publisher. [E-Book] (Updated 24 Jan 2019) Tersedia di: https://books.google.com/ [Accessed 22 Febuari 2019] 